\title{
Forest Carbon Stocks in Woody Plants of Tara Gedam Forest: Implication for Climate Change Mitigation
}

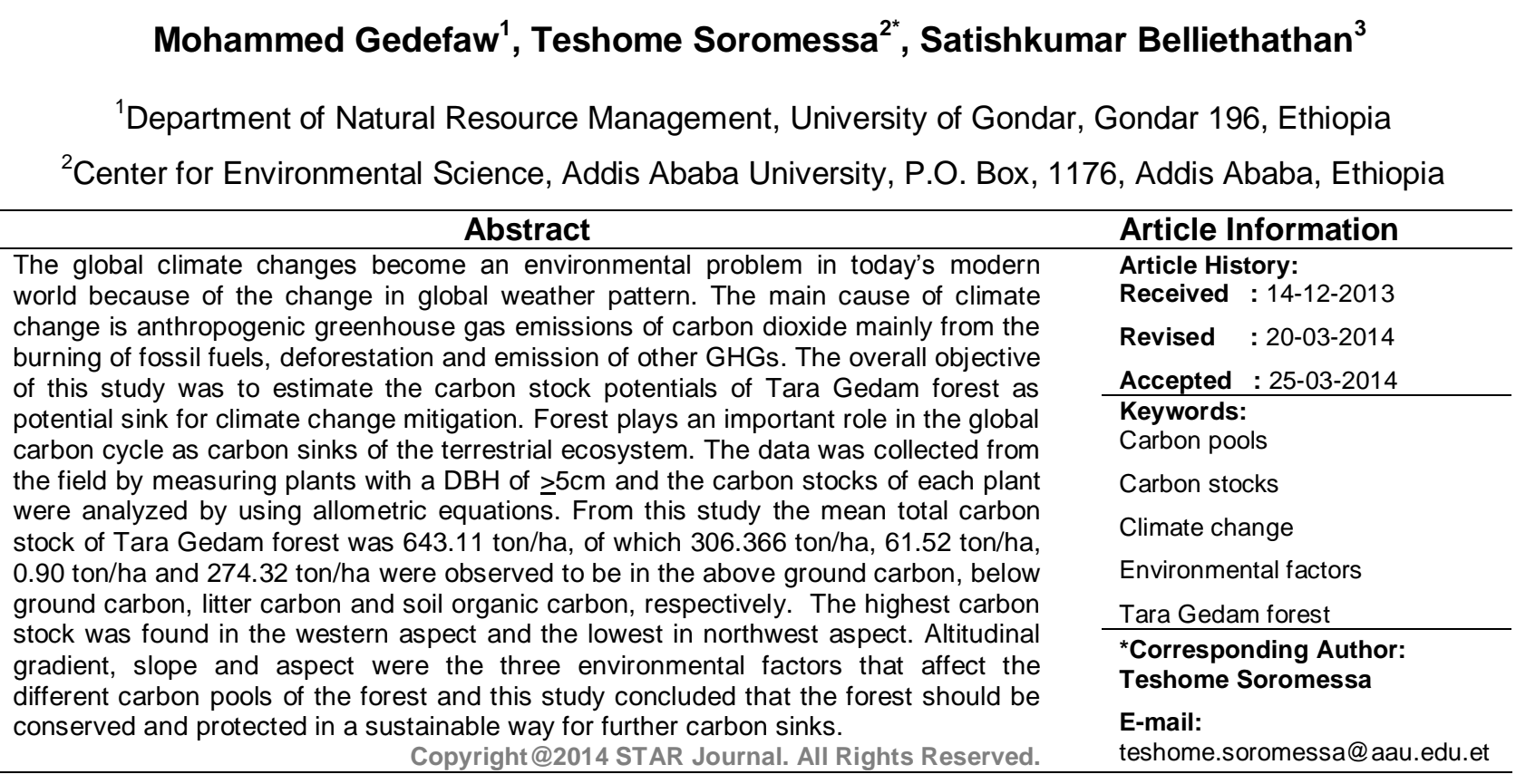

\section{INTRODUCTION}

The global climate change become an environmental problem in today's modern world because of the colossal threat, risks and effects that it poses to the global weather patterns, global warming, natural ecosystems, biodiversity, the oceans and seas, and the future of human life and existence on planet earth (Freestone and Streck, 2009). This is mainly caused by anthropogenic greenhouse gas emissions of carbon dioxide mainly from the burning of fossil fuels, deforestation and emission of other greenhouse gas.

Within the portfolio of climate change mitigations options, carbon capture and storage has emerged as one of the most promising greenhouse gas reduction technologies with enormous potential to achieve significant cuts in $\mathrm{CO}_{2}$ emissions from fossil fuels (Bielicki , 2007). Forests are known in contributing to green house gas reductions through carbon sequestration (Brand, 1998; Metz et al., 2001; Lubowski et al., 2006). These benefits can be perceived to be more important at the global than at national, regional or local levels (Sharma, 2000).

The emission of these greenhouse gases due to the different human activities leads to the cause of change in climate pattern and have growing by a faster rate since the beginning of industrial development, with an increasing rate of $70 \%$ between 1970 and 2004 (IPCC, 2007a). In the past 60 years, the amount of anthropogenic carbon dioxide emitted to the atmosphere, primarily because of expanding use of fossil fuels for energy, has risen from pre-industrial levels of 280 parts per million to present levels of over 365 parts per million. This increase has been implicated in a gradual increase in the Earth's temperature.

In Ethiopia, people particularly in the rural areas, are highly dependent on forest resources to fulfill their basic needs such as fuel wood for cooking, heat, foliage for livestock, and timber for shelter and non timber forest for medicine in the absence or unaffordable cost of alternative options. Deforestation, forest degradation, forest fire and burning of fossil fuel are playing a significant role in producing the green house gases (IPCC, 2000).

Even if this study only covers very small area looking from the Ethiopian total forest coverage and only small sample areas of the study site, it is important for sustainable forest management by achieving win-win strategy. No study has been conducted in Tara Gedam forest that aimed at carbon sequestration. Therefore, this study was taken up to estimate the carbon stock capacity of Tara Gedam forest by quantifying the major carbon 
Mohammed Gedefaw et al.,

pools and to see the variations of the carbon stock density of different carbon pools under different environmental factor (altitude, slope and aspect).

\section{MATERIALS AND METHODS}

\section{Description of the Study Area}

This study was undertaken in Tara Gedam forest, Amhara National Regional State, South Gondar, Ethiopia located at about $640 \mathrm{~km}$ North of Addis Ababa. Tara Gedam Forest is one of the remnant dry afromontane
Sci. Technol. Arts Res. J., Jan-March 2014, 3(1): 101-107

forests in Ethiopia and the forest has an altitudinal gradient ranging from 2217 to $2457 \mathrm{~m}$ above sea level with the highest peak at Wombera Mountain. The forest covers 475 hectares. The study area is characterized by moderate climate, locally known as woina dega and it has a mono modal rainfall distribution and the rainy season is from June to August which ranges from $900 \mathrm{~mm}$ to 1,200 $\mathrm{mm}$ and the mean annual maximum and minimum temperatures are $27.9^{\circ} \mathrm{C}$ and $11.1^{\circ} \mathrm{C}$, respectively.

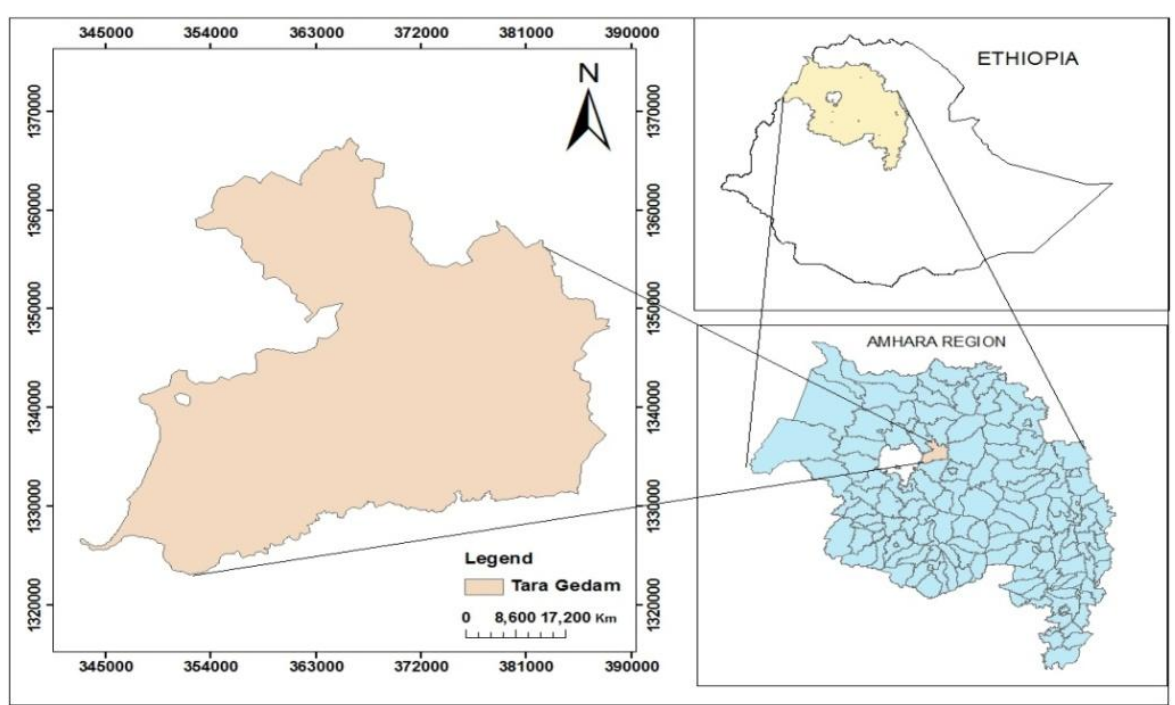

Figure 1: Location map of the study area.

\section{Delineation of the Study Site}

Delineation of the forest boundaries was the first step in forest carbon stock measurement .The boundaries of the study forest area was delineated by taking geographic coordinates with GPS at each turning point. The GPS points that were taken from the study site to indicate each sample plots were recorded.

\section{Sampling Techniques on the Field}

Simple random sampling method was used to take samples. Sample plots were laid along line transects based on altitudinal variation of the study area. A randomly sampling plot of $(10 \mathrm{~m} \times 20 \mathrm{~m})$ in each site was established. To reveal the tree composition and biomass, all live trees with a diameter $\geq 5 \mathrm{~cm}$ were recorded as indicated by (Pearson et al., 2005). The diameter was measured at breast height $(\mathrm{DBH}, 1.3 \mathrm{~m}$ height from the ground) to estimate biomass and the size class distribution of trees in a sampling plot. $\mathrm{DBH}$ was measured by using tree Caliper and measuring tape. Trees with multiple stems connected near the ground were counted as single individuals and bole circumference was measured separately. Tree height was recorded by using a measuring hypsometer. The methodology and procedures used to estimate carbon stocks were simple step by step procedures using standard carbon inventory principles and techniques (Pearson et al., 2005). Procedures were based on data collection and analysis of carbon accumulating in the above ground biomass, below-ground biomass, leaf litter, and soil carbon of forests using verifiable modern methods.

\section{Stratification of the Study Area}

Stratification was done in the forest in order to take accurate data from the field as well as to maintain the homogeneity of the area. Altitude was the major parameter to classify the study area. The strata were defined at each elevation, starting from the bottom to the top of the mountain. Based on altitudinal variation, the study site was stratified into three zones namely: lower (2217-2275 m), middle (2276-2350 $\mathrm{m}$ ) and higher (>2351$2457 \mathrm{~m}$ ). Slope gradient was the second parameter to classify the area. Therefore, slope classes classified into lower $(0-20 \%)$, middle $(20.5-40 \%)$ and higher (>40\%). Aspect was also another parameter that was considered in the study forest and classified in to eight classes: $\mathrm{N}$ (North), NE (Northeast), S (South), SE (Southeast), E (East), NW (Northwest), W (West) and SW (Southwest).

\section{Field Measurements}

Sample plots $(10 \mathrm{~m} \times 20 \mathrm{~m})$ were laid through stratified random sampling method with nine transect lines in the various qualitatively classified biomass levels to account for the largest variability in the biomass range. Ground inventory data of tree parameters i.e., DBH and height of the trees were collected.

\section{Vegetation Data Collection and Identification}

The estimations of above and below ground carbon depend on the above ground biomass of living tree species. To estimate the above ground biomass all tree species within selected sample plots $\mathrm{DBH} \geq 5 \mathrm{~cm}$ were identified and recorded. Trees with multiple stems at 1.3 $\mathrm{m}$ height were treated as a single individual and $\mathrm{DBH}$ of the largest stem was taken. Plant identification were done by using Flora of Ethiopia and Eritrea.

\section{Field Carbon Stock Measurement}

The major activities of carbon measurement during the field data collection were above-ground tree biomass, below-ground biomass, leaf litter, and soil organic carbon 
Mohammed Gedefaw et al.,

measurements. Detailed methods are explained under the following sub headings.

\section{Above Ground Biomass (AGB)}

The above ground biomass consists of all living vegetation above the soil, inclusive of stems, stumps, branches, bark, seeds and foliage. The DBH (at 1.3m) and height of individual trees greater than or equal to $5 \mathrm{~cm}$ and $\mathrm{DBH}$ were measured in each sampling plots.

\section{Litter Biomass (LB)}

The leaf litter is defined as all dead organic surface material on top of the mineral soil. A quadrate with a size of $1 \mathrm{~m} \times 1 \mathrm{~m}$ was established to sample litters. In each sample plots a total of five small quadrates were laid four at the corner and one in the center to minimize heterogeneity. The litter samples were taken in sub quadrate of $(1 \mathrm{~m} \times 1 \mathrm{~m})$ along diagonal from one corner to the other and then the leaf litters within the $1 \mathrm{~m}^{2}$ sub plots were collected.

Laboratory analysis: The 100 gram sub sample fresh weights were sampled from the five sub-samples collected from each quadrant which were mixed homogenously and then taken to laboratory and oven dried at $105^{\circ} \mathrm{C}$.

\section{Soil Organic Carbon (SOC)}

Soil samples were collected from the field with five sub-plots within each major plot. The Samples were dug using core sampler with a diameter of $5 \mathrm{~cm}$ and the depth of the soil in which that took the sample was $30 \mathrm{~cm}$. Mixing of soils was done properly by taking equal amount of soil from each sub plots to make a composite in order to make homogeneity. After organizing the samples in such a way, the samples were taken to Wondo Genet College of forestry and Natural resources for laboratory analysis. In the laboratory, soils are prepared and oven dried at $105{ }^{\circ} \mathrm{C}$ for 24 hours to remove the soil moisture so as to determine the percentage of organic carbon. Finally, the bulk density and soil organic carbon were determined after getting percentage of organic carbon.

\section{Estimation of Carbon Stocks in Different Carbon Pools}

Estimation of Above Ground Carbon Stock (AGC)

Bhishma et al. (2010) defined allometric equation as a statistical relationship between key characteristic dimensions of trees that are fairly easy to measure, such as $\mathrm{DBH}$ or height, and other properties that are more difficult to assess, such as above ground biomass. The equation used to calculate the above ground biomass is given below:

$A G B=34.4703-8.0671(D B H)+0.6589\left(D H^{2}\right) \ldots$ (equ. 2$)$

Where, $A G B$ is above ground biomass, $\mathrm{DBH}$ is diameter at breast height.

\section{Estimation of Below Ground Carbon Stock (BGC)}

Below ground biomass estimation is much more difficult and time consuming than estimating aboveground biomass (Geider et al., 2001). Roots play an important role in the carbon cycle as they transfer considerable amounts of Carbon to the ground, where it may be stored for a relatively long period of time. As indicated by MacDicken (1997), standard method for estimation of below ground biomass can be obtained as $20 \%$ of above
Sci. Technol. Arts Res. J., Jan-March 2014, 3(1): 101-107

ground tree biomass i.e., root to shoot ratio value of $1: 5$ is used. The equation is given below:

$\mathrm{BGB}=\mathrm{AGB} \times 0.2$ (equ.3)

Where, BGB is below ground biomass, $A G B$ is above ground biomass, 0.2 is conversion factor (or $20 \%$ of AGB).

\section{Estimation of Carbon Stocks in the Litter Biomass}

According to Pearson et al. (2005), estimation of the amount of biomass in the leaf litter can be calculated by:

$$
\mathbf{L B}=\frac{\text { Wfield }}{\mathrm{A}} * \frac{\text { Wsub sample }(\mathrm{dry})}{\text { Wsub sample }(\text { fre } \mathrm{sh})} * \frac{1}{10,000} \ldots \ldots \ldots \ldots \text { (equ.4) }
$$

Where: $\mathrm{LB}=$ Litter biomass $\left(\mathrm{ha}^{-1}\right)$

$\mathrm{W}_{\text {field }}=$ Weight of wet field sample of litter sampled within an area of size $1 \mathrm{~m}^{2}(\mathrm{~g})$;

$A=$ Size of the area in which litter were collected (ha);

W sub-sample, dry = Weight of the oven-dry sub-sample of litter taken to the laboratory to determine moisture content $(\mathrm{g})$, and

W sub-sample, fresh $=$ Weight of the fresh sub-sample of litter taken to the laboratory to determine moisture content (g).

The carbon content of vegetation is surprisingly constant across a wide variety of tissue types and species. Schlesinger (1991) noted that Carbon content of biomass is almost always found to be between 45 and $50 \%$ (by oven dry mass). In many applications, the carbon content of vegetation is estimated by simply taking a fraction of the biomass by multiplying 0.5 .

Where

$$
C=0.5^{\star} L B
$$

$\mathrm{C}=$ is carbon content by mass, and

$\mathrm{LB}=$ is oven-dry biomass.

Therefore, total carbon content of litter (ton/ha) =Total dry litter biomass* carbon fraction

$$
\mathrm{C}_{\mathrm{L}}=\mathrm{LBM} \times \% \mathrm{C}
$$

Where, $C_{L}$ is total carbon stocks in the litter in ton/ha, \%C is carbon fraction determined in the laboratory (Pearson et al., 2005).

\section{Estimation of Soil Organic Carbon (SOC)}

The carbon stock of soil was done by using the following formula which is recommended by Pearson et al. (2005) from the volume and bulk density of the soil.

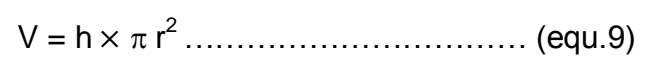

Where, $\mathrm{V}$ is volume of the soil in the core sampler in $\mathrm{cm}^{3}$, $\mathrm{h}$ is the height of core sampler in $\mathrm{cm}$, and $\mathrm{r}$ is the radius of core sampler in cm (Pearson et al., 2005). More over the bulk density of a soil sample was calculated as follows:

$$
\mathrm{BD}=\frac{\text { Wav , dry }}{\mathrm{V}}
$$

Where, BD is bulk density of the soil sample per, $\mathrm{W}_{\mathrm{av}}$, dry is average air dry weight of soil sample per the quadrant, $\mathrm{V}$ is volume of the soil sample in the core sampler auger in $\mathrm{cm}^{3}$ (Pearson et al., 2005).

$$
\mathrm{SOC}=\mathrm{BD} * \mathrm{D} * \mathrm{C}
$$

Where, $\mathrm{SOC}=$ soil organic carbon stock per unit area $(\mathrm{t}$ $\mathrm{ha}^{-1}$ )

$$
\mathrm{BD}=\text { soil bulk density }\left(\mathrm{g} \mathrm{cm}^{-3}\right) \text {, }
$$


Mohammed Gedefaw et alo,

$D=$ the total depth at which the sample was taken (30 $\mathrm{cm})$, and

$$
\% \mathrm{C}=\text { Carbon concentration (\%) }
$$

\section{Estimation of Total Carbon Stock Density}

The total carbon stock is calculated by summing the carbon stock densities of the individual carbon pools of the stratum using the Pearson et al. (2005) formula.

Carbon stock density of a study area:

$$
\mathrm{C}_{T}=\mathrm{AGC}+\mathrm{BGC}+\mathrm{LC}+\mathrm{SOC} \text {. }
$$

Where, $\mathrm{CT}=$ Total Carbon stock for all pools (ton/ha), $\mathrm{AGC}=$ above ground carbon stock (ton/ha), $\mathrm{BGC}=$ below ground carbon stock (ton/ha), LC=litter carbon stock (ton/ha) and SOC= soil organic carbon (ton/ha). The total carbon stock was then converted to tons of $\mathrm{CO}_{2}$ equivalent by multiplying it by $44 / 12$, or 3.67 as indicated by (Pearson et al., 2007).

\section{Statistical Analysis}

The data analysis of different carbon pools measured in the forests was organized by arranging and recording the data on the excel data sheet. The data obtained from the study site such as DBH, height of each species, wet weight, fresh weight and dry weight of litter and soil were analyzed using Statistical Package for Social Science (SPSS) software version 20 . In order to apply appropriate
Sci. Technol. Arts Res. J., Jan-March 2014, 3(1): 101-107

models for biomass estimation, the height and diameter data were arranged in classes and the environmental factors were also classified in different sections for similar pattern analysis. Based on these classifications, the $\mathrm{DBH}$ and height of trees were classified into five classes: $0-10$, $11-20,21-30,31-40$ and $>40$. Differences at the $95 \%$ $(\alpha=0.05)$ confidence interval was used to see the significance differences.

\section{RESULTS}

\section{Carbon Stock in the Different Carbon Pools}

The carbon stock value of the study site in different carbon pools showed different storage of Carbon.

About $82.92 \%$ of the biomass was contained in above ground, while below ground biomass comprised $17.08 \%$ of the total biomass. It was found that about $0.0028 \%$ of the biomass was contained in the litter. The carbon stock that was stored in the AGB was $47.64 \%$ whereas $42.67 \%$ was contained in the soil. The least amount of carbon was stored in litter carbon pool $(0.14 \%)$ followed by below ground carbon pool (9.57\%). The mean carbon density in all carbon pool of the study site was 643.11 ton/ha. The overall summary of mean biomass and carbon stock in all plots of the study site is shown in Table 1.

\begin{tabular}{|c|c|c|c|c|c|c|c|}
\hline Total No of plots & \multicolumn{7}{|c|}{ Different Carbon pools } \\
\hline $\begin{array}{c}71 \\
\text { Mean values in ton/ha }\end{array}$ & $\begin{array}{c}\text { AGB } \\
\mathbf{5 8 8 . 1 7}\end{array}$ & $\begin{array}{c}\text { BGB } \\
\mathbf{1 2 1 . 1 4}\end{array}$ & $\begin{array}{l}\mathrm{LB} \\
0.02\end{array}$ & $\begin{array}{c}\text { AGC } \\
306.37\end{array}$ & $\begin{array}{l}\text { BGC } \\
61.52\end{array}$ & $\begin{array}{c}\text { LC } \\
\mathbf{0 . 9 0}\end{array}$ & $\begin{array}{c}\text { SOC } \\
274.32\end{array}$ \\
\hline
\end{tabular}

Table 1: Summary of mean biomass and carbon stock of AGB, AGC, BGB, BGC, LB, LC and SOC of the study site.

Table 2: Percentage biomass and carbon density in the different carbon pools

\begin{tabular}{cccccccc}
\hline \multirow{2}{*}{ Total No of plots } & \multicolumn{7}{c}{ Different Carbon pools } \\
\cline { 2 - 7 } & AGB (\%) & BGB (\%) & LB (\%) & AGC (\%) & BGC (\%) & LC (\%) & SOC (\%) \\
\hline $\mathbf{7 1}$ & 82.92 & 17.08 & 0.0028 & 47.64 & 9.56 & 0.14 & 42.66 \\
Mean values in ton/ha & $\mathbf{5 8 8 . 1 7}$ & $\mathbf{1 2 1 . 1 4}$ & $\mathbf{0 . 0 2}$ & $\mathbf{3 0 6 . 3 7}$ & $\mathbf{6 1 . 5 2}$ & $\mathbf{0 . 9 0}$ & $\mathbf{2 7 4 . 3 2}$ \\
\hline AGB: Above ground biomass; AGC: Above ground carbon; BGB: Below ground biomass; BGC: Below ground carbon; LB: Litter Biomass; LC:
\end{tabular}

Litter carbon; SOC: Soil organic carbon).

\section{Factors affecting the Carbon Stocks of the Study Site}

There are different factors that affect the storage of carbon in forests. Among the many factors, altitude, slope and aspect have a pronounced effect on carbon concentration. Each is discussed as follow

\section{Carbon Stocks of Different Pools and Altitudinal Variation}

The presence of variation in altitudinal gradient affects the carbon stock of different pools in the forest. The middle parts of altitude is high in above ground carbon stocks while the lower and upper parts of altitude have low to moderate carbon stocks in above ground biomass. 263.004, 373.065 and 203.505 ton/ha carbon stocks were recorded at the lower, middle and upper altitude respectively in above ground biomass. Similar trend was shown in below ground biomass in which 52.6, 74.613 and 42.052 ton/ha carbon stocks were recorded in the lower, middle and upper altitude respectively with highest value found at the middle part of altitudinal classes followed by the lower and upper parts. But this is not very much significance at $95 \%$ confidence interval $(F=1.577$, $P=0.214)$ in $A G C$ and $(F=1.505, P=0.229)$ in $B G C$ stocks. However, in the case of litter carbon stock and SOC, the trend changed. There was a significance difference at $\alpha=0.059(F=3.222, P=0.046)$ in litter carbon stock and $(F=6.207, P=0.003)$ SOC stocks. The litter carbon stock was higher in the lower parts of altitude and low in the upper altitude. The carbon stock in the soil pool was higher in upper altitude and lower in the lower altitude with moderate carbon stocks in the middle altitudinal classes. $192.89,304.42$ and 337.36 ton/ha stocks of carbon were recorded in the lower, middle and upper altitude respectively in the soil pool. In general, the upper part of the altitude contains more carbon stocks (583.7904 ton/ha), followed by the middle (752.9993 ton/ha) and the lower altitudinal gradient (752.9993 ton/ha).

\section{Carbon Stocks of Different Pools and Slope Gradient}

The slope gradient was also a second factor which affects the carbon stocks of different pools in the studied forest. Above ground biomass and below ground biomass and their consecutive carbon stocks were found to be low in hilly areas of the forest due to the fact that no more vegetations cover were found there. The carbon stocks of the middle slope gradient was higher in both above ground carbon and below ground carbon stocks and lower in the lower and higher slope gradient in both pools. $219.516,361.623$ and 274.212 ton/ha carbon stocks were recorded at the lower, middle and upper slope gradient respectively in above ground carbon stocks. Similar trend was also shown in below ground biomass in which 43.902, 72.326 and 55.492 ton/ha carbon stocks were recorded in the lower, middle and higher slope classes respectively with highest value found at the middle of slope classes followed by the higher and lower slope 


\section{Mohammed Gedefaw et al.,}

classes. But this was not statistically significance at $\alpha=0.05(F=0.646, P=0.528)$ in above ground biomass and $(F=0.627, P=0.537)$ in below ground biomass. However, in the case of litter carbon stock and SOC, there was a significance difference at $\alpha=0.05$. The litter carbon stock was higher in the middle slope classes and low in the higher slope classes with its value arranged 0.964, 1.092 and 0.683 ton/ha in the lower, middle and higher slope gradient respectively. The carbon stock in the soil pool was higher in upper slope classes and lower in the lower slope classes with moderate carbon stocks in the middle slope classes. 223.869, 234.941 and 345.265 ton/ha stocks of carbon were recorded in the lower, middle and upper slope classes respectively in the soil pool. In general, the upper slope class contains more carbon stocks ( 675.652 ton/ha), followed by the middle (669.982 ton/ha) and the lower slope gradient (488.251 ton/ha).

\section{Carbon stocks of different pools and aspect}

Aspect was another parameter that affects the carbon stocks of different pools through which the direction of the
Sci. Technol. Arts Res. J., Jan-March 2014, 3(1): 101-107

plots were found to determine in which direction the highest and lowest carbon stocks is found in the study forest. Based on the result that obtained, the mean AGC stock was lowest in NW (179.9 ton/ha) and highest in W (836.98 ton/ha). Similar trend was observed for carbon stocks in below ground carbon pool with the highest value 167.3971 ton/ha in West (W) direction and 35.98143 ton/ha in North West (NW) direction. On the other hand, the highest carbon stocks in litter biomass was recorded in the NW (1.422574 ton/ha) and the minimum carbon stock was recorded in west (W) $(0.516483$ ton/ha aspect. The carbon stocks in soil was also recorded the minimum value in southeast (SE) (194.8459 ton/ha) and the highest or maximum value south (S) (432.6206 ton/ha) in direction. In all carbon pools there was a significance difference in carbon stocks of the forest at 95\% confidence interval $(\alpha=0.05)$. In general, the highest carbon stock was recorded in west $(\mathrm{W})$ aspect (1365.8962 ton/ha) and the minimum carbon stock recorded was in the North West (NW) (416.5258 ton/ha) direction (table).

Table 3: Mean biomass and carbon stocks (t ha-1) in different carbon pools along altitudinal range.

\begin{tabular}{ccccccc}
\hline Altitude class & Altitude range $(\mathbf{m})$ & AGC & BGC & LC & SOC & Total carbon Stock ton/ha \\
\hline Lower & $2217-2275$ & 263.004 & 52.6 & 1.165 & 192.89 & 509.6612 \\
Middle & $2276-2350$ & 373.065 & 74.613 & 0.901 & 304.42 & 752.9993 \\
Upper & $2351-2457$ & 203.505 & 42.052 & 0.873 & 337.36 & 583.7904 \\
\hline
\end{tabular}

Table 4 Carbon stocks in different pools with respect to slope gradient.

\begin{tabular}{cccccccc}
\hline Slope Class & $\begin{array}{c}\text { Slope } \\
\text { Range (\%) }\end{array}$ & $\begin{array}{c}\text { No of } \\
\text { Plots }\end{array}$ & $\begin{array}{c}\text { AGC } \\
\text { (ton/ha) }\end{array}$ & $\begin{array}{c}\text { BGC } \\
\text { (ton/ha) }\end{array}$ & $\begin{array}{c}\text { LC } \\
\text { (ton/ha) }\end{array}$ & $\begin{array}{c}\text { SOC } \\
\text { (ton/ha) }\end{array}$ & $\begin{array}{c}\text { Total } \\
\text { ton/ha }\end{array}$ \\
\hline Lower & $0-20$ & 11 & 219.516 & 43.902 & 0.964 & 223.869 & 488.251 \\
Middle & $20.5-40$ & 33 & 361.623 & 72.326 & 1.092 & 234.941 & 669.982 \\
Higher & $>40$ & 27 & 274.212 & 55.492 & 0.683 & 345.265 & 675.652 \\
\hline
\end{tabular}

Table 5: Mean carbon stocks (ton/ ha) different pools in different aspect.

\begin{tabular}{ccclcll}
\hline Aspect & $\begin{array}{c}\text { No of } \\
\text { plots }\end{array}$ & $\begin{array}{c}\text { ABGC } \\
\text { (ton/ha) }\end{array}$ & $\begin{array}{c}\text { BGC } \\
\text { (ton/ha) }\end{array}$ & $\begin{array}{c}\text { LC } \\
\text { (ton/ha) }\end{array}$ & $\begin{array}{c}\text { SOC } \\
\text { (ton/ha) }\end{array}$ & Total \\
\hline S & 11 & 227.1973 & 47.03636 & 0.629906 & 432.6206 & 707.48417 \\
SW & 8 & 374.9588 & 74.99 & 0.825913 & 338.4288 & 789.20351 \\
SE & 6 & 362.6483 & 72.52997 & 0.771207 & 194.8459 & 630.79538 \\
N & 11 & 216.5836 & 43.31545 & 1.027394 & 195.5808 & 456.50724 \\
NW & 8 & 179.9 & 35.98143 & 1.422574 & 199.2218 & 416.5258 \\
E & 11 & 244.0155 & 48.80182 & 0.971197 & 231.1891 & 524.97762 \\
NE & 10 & 189.249 & 37.851 & 1.039895 & 222.5504 & 450.6903 \\
W & 6 & 836.978 & 167.3971 & 0.516483 & 361.0046 & 1365.8962 \\
\hline
\end{tabular}

Table 6: One-way ANOVA results of the three factors indicated above were shown below to show a significance difference in the carbon stocks values of different pools:

\begin{tabular}{cccc}
\hline Environmental factors & Carbon pools & F-value & P-value \\
\hline & AGC & 1.577 & 0.214 \\
ALTITUDE & BGC & 1.505 & 0.229 \\
& LC & 3.222 & 0.46 \\
& SOC & 6.207 & $\mathbf{0 . 0 0 3}$ \\
\hline \multirow{3}{*}{ SLOPE } & AGC & 0.646 & 0.528 \\
& BGC & 0.627 & 0.537 \\
& LC & 3.654 & $\mathbf{0 . 0 3 1}$ \\
& SOC & 6.044 & $\mathbf{0 . 0 0 4}$ \\
\hline \multirow{2}{*}{ ASPECT } & AGC & 3.479 & $\mathbf{0 . 0 0 3}$ \\
& BGC & 3.474 & $\mathbf{0 . 0 0 3}$ \\
& LC & 2.726 & $\mathbf{0 . 0 1 6}$ \\
& SOC & 5.530 & $\mathbf{0 . 0 0 0}$ \\
\hline
\end{tabular}

\section{DISCUSSION}

\section{Storage of Biomass in Different Pools}

The maximum above ground biomass per plot was 5035.16 ton/ha and the minimum was 24.57 ton/ha. The average biomass stock recorded in above ground biomass was 588.17 ton/ha. The results are more or less similar to the previous researches of above ground biomass of afromontane forest which were $403 \mathrm{ton} / \mathrm{ha}$, 
Mohammed Gedefaw et al.,

754.5 ton/ ha, and 567.2 ton/ ha as indicated by (Getachew Tesfaye, 2007). The average above ground biomass observed from these three location was 574.89 ton/ha. The global above ground biomass in tropical dry and wet forests ranged between $30-275$ ton/ha and 2131173 ton/ha respectively as indicated by Murphy and Lugo (1986), which is lower than the above ground biomass of Tara Gedam forest.

In this study, the differences in biomass and carbon accumulation among plots could be largely due to differences in the growth rates of plants as indicated by (Redondo, 2007). Litter constitutes an important flux of soil organic Carbon. The forest litter consisted of a relatively high number of trees, although the density varies among samples and species; in densely populated trees few litters were found due to the closeness of plants each other makes their litter not fall down (Demel Teketay, 1996). The Carbon stocks in the litter of the study forest ranged from 0.36 to 3.29 ton/ha which were comparable to those reported for tropical seasonal rainforests (1.4 ton/ha) carbon (Lüet et al., 2010) and tropical secondary forest at the Makiling Forest Reserve in the Philippines (1.9 ton/ha) Lasco et al. (2004). On the
Sci. Technol. Arts Res. J., Jan-March 2014, 3(1): 101-107

other hand, the litter carbon varies on other tropical forests (2.6-3.8 ton/ha) as reported by Brown and Lugo (1982). The relatively low quantities of Carbon stored in litter carbon stock in the studied forest may be due to the high decomposition rate as reported in a 10-year study by Tang et al. (2010).

The average values of soil organic carbon in the study area was 274.322 ton/ha, which was similar to the Carbon density estimates of Afromontane Rain Forests of the Eastern Arc Mountains which were found to be between 252 and 581 ton/ha as indicated by (Munishi (2001); Munishi and Shear (2004). The distribution of Carbon stocks in each sample plot of the study forest is known to vary due to the presence of different tree species, soil nutrient availability, climate, and topography and disturbance regime (Houghton, 2005). This indicates that, the higher soil organic carbon in the soil could sequester more $\mathrm{CO}_{2}$. The bulk density of the soil in this study was found to be $0.343 \mathrm{~g} / \mathrm{cm}^{3}$ minimum value and $1.276 \mathrm{~g} / \mathrm{cm}^{3}$ maximum value with an average value of $0.672 \mathrm{~g} / \mathrm{cm}^{3}$ The presence of low bulk density in the soil indicates that the soil has high potentials to accumulate large amount of organic matter in it (Brady, 1974).

Table 7: Comparison of carbon stock (ton/ ha) of the present result with other studies (AGC: Above ground carbon; BGC: Below ground carbon; LC: Litter carbon; SOC: Soil organic carbon).

\begin{tabular}{ccccc}
\hline \multicolumn{1}{c}{ Study places } & AGC & BGC & LC & SOC \\
\hline Egdu Forest (Adugna Feyissa, 2012) & 278.08 & 55.62 & 3.47 & 277.56 \\
Menagasha Sub a State Forest ( Mesfin Sahile, 2011) & 133 & 26.99 & 5.26 & 121.28 \\
Selected Church Forest (Tulu Tola, 2011) & 122.85 & 25.97 & 4.95 & 135.94 \\
\hline Tara Gedam Forest & $\mathbf{3 0 6 . 3 6}$ & $\mathbf{6 1 . 5 2}$ & $\mathbf{0 . 9 0}$ & $\mathbf{2 7 4 . 3 2}$ \\
\hline
\end{tabular}

\section{Environmental Factors Affecting the Carbon Stocks of Different Pools}

Altitudinal gradient, slope and aspects were the factors that affect the storages of carbon in different pools in study site. For example, Jordi Garcia-Pausas et al. (2000) observed a strong effect of slope and aspect on the SOC stock of subalpine forest in the Olympic Mountains of Washington state. The carbon stocks of the study forest were highest at the middle altitudinal range followed by the upper one and decreased at bottom part of the mountain. This may be due to the absence of dense and tallest trees at both end of the forest site and possibly also due to the favorable conditions for tree growth in the middle part. Especially, altitudinal variation has an impact on soil organic carbon stock because of its influence on soil water regime (Gulledge and Schimel, 2000). The carbon stock of the study forest increased as the degree of slope gradient increased. The density of trees followed the same pattern. In addition, the highest carbon stock was found in the western aspect and the least in the North-western part of the forest possibly due to the availability of moisture and fertile soil in the western part and less moisture and fertility in North-western part.

\section{CONCLUSION}

This study showed that the forest contains many diversified plant species. A total of fourty one different species of plants were collected, of which Olea europaea was the dominant and Acanthus sennii was the least dominant in the study site. Based on the structural composition of $\mathrm{DBH}$ and height class distribution on the Tara Gedam forest, similar trends observed in both these classes. The densities of tree species decreases as the $\mathrm{DBH}$ and height classes increases in the forest. This implies that, the predominance of small sized tree species in the lower classes than in the upper classes. The analysis of these two parameters in the study forest indicated that higher percentage of number of tree species in the lower than in the higher frequency classes. The carbon stocks of the study site shows a variation among the plots due to the presence of high biomass plants in some plots and low biomass in other plots. The average carbon stocks of the different carbon pools of this study was higher than most re-searches done in Ethiopia related to carbon sequestration potentials of forests. The presence of high carbon stocks in the study forest indicates its potentials in the mitigation of climate change. The ANOVA result showed that at 95\% confidence interval, the carbon stocks in the different carbon pools (AGC, BGC, LC and SOC) were different due to environmental factors. The middle parts of altitude was high in above ground and below ground carbon stocks while the lower and upper parts of altitude had low to moderate carbon stock in both carbon pools due to the fact that there were dense vegetation cover in the middle altitudinal range. On the contrary, the litter carbon stock was higher in the lower parts of altitude and low in the upper altitude. The carbon stock in the soil pool was higher in upper altitude and lower in the lower altitude with moderate carbon stocks in the middle altitudinal classes. The carbon stock of the middle slope gradient was higher in both AGC and BGC stocks and lower in the lower and higher slope gradient in both pools. On the other hand, the litter carbon stock was higher in the middle slope classes and low in the higher slope classes and the carbon stocks in the soil pool was higher in upper slope classes and lower in the lower slope classes with moderate carbon stocks in the middle slope classes. The mean AGC and BGC stocks were lowest in north western 


\section{Mohammed Gedefaw et al.,}

part of the forest and highest in Western parts. On the other hand, the highest carbon stocks in litter biomass were recorded in the north western part and the minimum carbon stock was recorded in western aspect. The carbon stocks in soil were also recorded the minimum value in southeastern part and the peak value in the southern part of the forest. In general, the carbon stocks in the different pools were arranged in this order $\mathrm{W}>\mathrm{SW}>\mathrm{S}>\mathrm{SE}>\mathrm{E}>\mathrm{N}>$ $\mathrm{NE}>\mathrm{NW}$.

\section{REFERENCES}

Adugna Feyissa (2012). Forest Carbon Stock and Variations along Environmental Gradients in Egdu Forest: Implications of Managing Forests for Climate Change Mitigation MSc. Thesis, Addis Ababa University, Addis Ababa, Ethiopia.

Bhishma, P.S., Shiva, S.P., Ajay, P., Eak, B.R., Sanjeeb, B., Tibendra, R.B., Shambhu, C. and Rijan, T. (2010). Forest Carbon Stock Measurement: Guidelines for measuring carbon stocks in community-managed forests. Asia Network for Sustainable Agriculture and Bioresources, publishing, Kathmandu, Nepal, Pp.17-43.

Bielicki, J.M., and Kalinowski, A. (2007). Getting it done in, Nicholls, T., ( $1^{\text {st }}$ Edition) Fundamentals of Carbon Capture Storage and Storage Technology, London, United Kingdom: The Petroleum Economist Limited, pp. 37.

Brady, N. C. (1974). The Nature and Properties of Soils, $8^{\text {th }}$ ed., Macmillan, New York.

Brand (1998). Branding Perspectives on Social Marketing", in NA - Advances in Consumer Research Volume 25, eds. Joseph W. Alba and J. Wesley Hutchinson, Provo, UT: Association for Consumer Research, Pp. 299-302.

Brown, S. and Lugo, A.E. (1982). The storage and production of organic matter in tropical forests and their role in the global carbon cycle. Biotropica 14: 161-187.

Demel Teketay (1996). Germination ecology of 12 indigenous and 8 exotic multipurpose leguminous species from Ethiopia. Forest Ecology and Management 80: 209-223.

Freestone and Streck (2009). Legal Aspects of Carbon Trading: Kyoto, Copenhagen, and beyond, First Edition, (London, United Kingdom; Oxford University Press).

Watchman, P.Q., Introduction, In: Watchman, P. Q., (First edition), Climate Change: A Guide to Carbon Law and Practice: The adverse effects of climate change has already been felt globally as seen from extreme events like flooding, heat waves, hurricanes, tornadoes, typhoons, rising sea and river levels, global warming, atmospheric pollution \& melting of the glaciers. Pp. 7-22.

Geider, J.R., Delucia, H.E., Falkowsk, G.P., Finzi, C.A., Grime, P.J., Grace, J., Kana, M.T., Roche, J. (2001). Primary productivity of planet earth: biological determinants and physical constraints in terrestrial and aquatic habitats. Global Change Biology 7: 849-882.

Getachew Tesfaye (2007). Structure, biomass and net primary production in a dry tropical afromontane forest in Ethiopia. Institute of plant physiology, University of Bayreuth, Germany.

Houghton, R.A. (2005). Aboveground forest biomass and the global carbon balance. Global Change Biology 11:945-58.

Intergovernmental Panel on Climate Change (2000). Land Use, Land Use Change \& Forestry. Special Report, InterGovernmental Panel on Climate Change. Cambridge University Press, Cambridge, UK, pp. 127-180.

Intergovernmental Panel on Climate Change. (2007a). Highlights from Climate Change (2007). The Physical Science Basis: Summary for Policy Makers. Contribution of Working Group I to the Fourth Assessment Report of
Sci. Technol. Arts Res. J., Jan-March 2014, 3(1): 101-107

the Intergovernmental Panel on Climate Change. Cambridge University Press, Institute of Terrestrial Ecology, Edinburgh, pp. 545-552.

Jordi Garcia-Pausas., Pere Casals., Lluı's Camarero., Carme Huguet., Maria-Teresa Sebastia., Roy Thompson. and Joan Romanya. (2000). Soil organic carbon storage in mountain grasslands of the Pyrenees: effects of climate and topography. Biogeochemistry 82(3): 279-289.

Lasco, R.D., Guillermo, I.Q., Cruz, R.V.O, Bantayan, N.C. \& Pulhin, F.B. (2004). Carbon stocks assessment of a secondary forest in Mount Makiling Forest Reserve, Philippines. Journal of Tropical Forest Science 16: 35-45.

Lubowski., Shawn Bucholtz., Roger Claassen., Michael J. Roberts., Joseph C. Cooper., Anna Gueorguieva. and Robert Johansson. (2006). Environmental Effects of Agricultural Land Use Change. The Role of Economics and Policy, USA.

Lü et., Yin, J.X., Jepsen, M.R. and Tang, J.W. (2010). Ecosystem carbon storage and partitioning in a tropical seasonal forest in Southwestern China. Forest Ecology and Management 260:1798-1803.

Metz, B., Davidson, O., Swart, R. and Pan, J. (2001). Climate Change Mitigation: Cambridge, U.K, Cambridge University Press.

MacDicken, K.G. (1997). A Guide to Monitoring Carbon Storage in Forestry and Agroforestry Projects. In: Forest Carbon Monitoring Program. Winrock International Institute for Agricultural Development, Arlington, Virginia.

Mesfin Sahile. (2011). Estimating and Mapping of Carbon Stocks based on Remote Sensing, GIS and Ground Survey in the Menagesha Suba State Forest. M.Sc. Thesis, Addis Ababa University, Addis Ababa.

Munishi, P.K.T. (2001). The Eastern Arc Mountains Forests of Tanzania: Their Role in Biodiversity and Water Resources Conservation and Net Contribution to Atmospheric Carbon. PhD Thesis, North Carolina State University, Raleigh, NC USA. Pp.128.

Munishi, P.K.T. and Shear, T.H. (2004). Carbon storage in afromontane rain forests of the Eastern Arc Mountains of Tanzania: their net contribution to atmospheric carbon. Journal of Tropical Forest Science 16: 78-93.

Murphy, P.G. and Lugo, A.E. (1986). Structure and biomass production of a dry tropical forest in Puerto Rica. Biotropica 18: 89-96.

Pearson, T., Walker, S. and Brown, S. (2005). Sourcebook for land-use, land-use chang and forestry projects: Winrock International and the Bio-carbon fund of the World Bank. Arlington, USA, pp. 19-35.

Redondo, A. (2007). Growth, carbon sequestration, and management of native tree plantations in humid regions of Costa Rica. New Forests 34: 253-268.

Schimel and Gulledge. (2000). Contribution of increasing $\mathrm{CO} 2$ and climate to carbon storage by ecosystems in the United States. Science, 287: 2004-2006.

Schlesinger, W.H. (1991). Biogeochemistry, an Analysis of Global Change. New York, USA, Academic Press.

Sharma, S.P. (2000). Valuation of carbon sequestration of a Gmelina arbores (Roxb) planttion in conception I, Sariaya quezon, Philippines.

Tang, J.W., Cao, M., Zhang, J.H., Li, M.H. (2010). Litterfall production, decomposition and nutrient use efficiency varies with tropical forest types in Xishuangbanna, SW China: a 10-year study. Plant and Soil 335: 271-288.

Tulu Tola. (2011). Estimation of carbon stock in church forests: implications for managing Church forest for carbon emission reduction. M.Sc Thesis, Addis Ababa Univeristy, Addis Ababa, Ethiopia. 